$\begin{array}{r}\text { Phinisi Integration Review } \\ \text { Vol. 2, No.1, Februari 2019 Hal 009-019 } \\ \text { Website: http://ojs.unm.ac.id/pir } \\ \text { p-ISSN: 2614-2325 dan e-ISSN: 2614-2317 } \\ \hline\end{array}$

\title{
Pengaruh Iklim Sekolah dan Kreativitas Pembelajaran Terhadap Prestasi Belajar IPS Peserta Didik di SD Kartika XX-I Kecamatan Mamajang Kota Makassar
}

\author{
Hartinawanti $^{(1)}$ \\ Pascasarjana Universitas Negeri Makassar \\ email: tina53344@gmail.com
}

\begin{abstract}
Abstrak. Penelitian ini bertujuan (i) mengetahui pengaruh antara iklim sekolah terhadap prestasi belajar IPS; (ii) mengetahui pengaruh antara kreativitas pembelajaran terhadap prestasi belajar IPS; dan (iii) mengetahui pengaruh secara bersama-sama antara iklim sekolah dan kreativitas pembelajaran terhadap prestasi belajar IPS di SD Kartika Jaya XX-I Kecamatan Mamajang Kota Makassar. Metode Penelitian menggunakan jenis penelitian ex post facto. Teknik pengumpulan data melalui kuesioner. Populasinya adalah seluruh siswa SD Kartika XX-I Kecamatan Mamajang Kota Makassar yang berjumlah 265 orang Tahun Ajaran 2018. Teknik penyampelan yang digunakan adalah multistage random sampling sehingga diperoleh sebanyak 159 orang siswa. Teknik analisis data yang digunakan adalah analisis deskriptif dan analisis inferensial. Hasil penelitian menunjukkan bahwa iklim sekolah berpengaruh signifikan terhadap prestasi belajar IPS, Hal ini menunjukkan bahwa jika iklim sekolah kondusif maka prestasi belajar peserta didik juga akan tinggi; kreativitas pembelajaran berpengaruh signifikan terhadap prestasi belajar IPS, hal ini menunjukkan bahwa jika kreativitas pembelajaran tinggi maka prestasi belajar peserta didik juga tinggi; Iklim sekolah dan kreativitas pembelajaran bersama-sama berpengaruh signifikan terhadap prestasi belajar IPS peserta didik di SD Kartika XX-I Kecamatan Mamajang Kota Makassar, hal ini menunjukkan bahwa interaksi antara iklim sekolah dan kreativitas pembelajaran akan menunjukkan prestasi belajar peserta didik yang tinggi.
\end{abstract}

Kata Kunci: iklim sekolah; kreativitas pembelajaran; prestasi belajar

\begin{abstract}
The study aims at examining (i) the influence of school climate on Social Sciences learning achievement at SD Kartika XX-I in Mamajang subdistrict of Makassar city, (ii) the influence of learning creativity on Social Sciences achievement at SD Kartika XX-I in Mamajang subdistrict of Makassar city, and (iii) the influences of school climate and learning creativity collaboratively on Social Sciences learning achievement SD Kartika XX-I in Mamajang subdistrict of Makassar city. The study employed ex-post factor research. Data were collected through questionnaire. The population was the entire students at SD Kartika XX-I in Mamajang subdistrict of Makassar city with the total of 265 students of academic year of 2018. Samples were selected by employing multistage random sampling technique and obtained 159 students. Data were analyzed by using descriptive analysis and inferential analysis. The result of the study reveals that the school climate gives significant influences on Social Sciences learning achievement at SD Kartika XX-I in Mamajang subdistrict of Makassar city. It shows that if the school climate is conducive, the learning achievement will be higher as well. The learning creativity gives significant influence on Social Sciences learning achievement at SD
\end{abstract}


Kartika XX-I in Mamajang subdistrict of Makassar city. It shows that if learning creativity is higher, the learning achievement is also higher. The school climate and learning creativity collaboratively give significant influence on Social Sciences learning achievement at SD Kartika XX-I in Mamajang subdistrict of Makassar city. It shows that the interaction between school climate and learning creativity will show high learning achievement of students.

Keywords: school climate; learning creativity; leraning achievement

Ini adalah artikel dengan akses terbuka dibawah licenci CC BY-NC-4.0

(https://creativecommons.org/licenses/by-nc/4.0/).

\section{PENDAHULUAN}

Menurut (Syah 2012:195), "Prestasi belajar adalah tingkat keberhasilan peserta didik dalam mencapai tujuan yang ditetapkan dalam sebuah program". Salah satu bidang studi yang memiliki peranan penting dalam pendidikan adalah IPS. IPS merupakan salah satu ilmu pengetahuan yang tujuan pengajarannya adalah agar siswa mampu menguasai konsep-konsep dan mengkaitkan antar konsep serta mampu menggunakan konsep-konsep itu dalam metode ilmiah untuk memecahkan masalah dalam kehidupan sehari-hari.

Optimal atau tidaknya prestasi belajar dapat dipengaruhi oleh berbagai faktor. Faktor-faktor yang berasal dari dalam diri peserta didik terdiri dari faktor fisiologis meliputi kondisi jasmani dan panca indera, dan faktor psikologis meliputi inteligensi, perhatian, motivasi, bakat, kreativitas, motif, kematangan, dan kesiapan. Sedangkan faktor yang berasal dari luar peserta didik yaitu faktor lingkungan yang terdiri dari lingkungan alam dan lingkungan sosial, dan faktor instrumen pendidikan yang terdiri dari kurikulum, program, media pembelajaran, metode mengajar guru dan tenaga pengajar.

Berbagai faktor tersebut saling berhubungan satu sama lain, apabila dapat terpenuhi dengan baik, maka peserta didik akan merasa nyaman dan mudah menyerap materi yang dipelajarinya sehingga prestasi belajar peserta didik tersebut akan semakin baik. Sebagian besar waktu belajar peserta didik adalah ketika peserta didik tersebut berada di sekolah. Jika lingkungan sekolah atau yang biasa kita sebut dengan iklim sekolah terasa nyaman, maka peserta didik akan lebih berkonsentrasi dan bersemangat dalam belajar.
Iklim sekolah adalah suatu keadaan yang dapat diamati dan diinterpretasikan oleh peserta didik yang meliputi kondisi sekolah yang diciptakan dari perpaduan antara norma, kebiasaan dan interaksi antar berbagai faktor (pribadi, sosial, dan budaya) yang mempengaruhi sikap civitas sekolah yang mengarah pada prestasi peserta didik yang tinggi.

Kreativitas pembelajaran peserta didik memiliki empat komponen penting, yakni: bahan ajar, suasana belajar, media dan sumber belajar, serta guru sebagai subjek pembelajaran. Komponen-komponen tersebut sangat mempengaruhi proses pembelajaran peserta didik. Suasana belajar yang nyaman dan menyenangkan mampu memberikan fokus pada peserta didik dengan apa yang diberikan sehingga dapat mengembangkan kreativitasnya.

Berdasarkan hasil observasi awal diketahui bahwa iklim sekolah di SD Kartika XX-I Kecamatan Mamajang Kota Makassar terbilang baik, hal ini terlihat dari hubungan antar civitas sekolah yang sudah terjalin dengan baik dengan membiasakan budaya saling bersalaman dan menyapa setiap bertatap muka, karyawan sekolah memberikan pelayanan yang baik dan ramah kepada peserta didik, kepala sekolah secara berkala memantau suasana belajar mengajar peserta didik dikelas. Suasana sekolah terbilang nyaman terlihat dari banyaknya tumbuhan hijau di sekolah sehingga dapat peserta didik belajar dengan tenang. Namun, ternyata yang terjadi adalah hal sebaliknya dimana prestasi belajar peserta didik masih belum optimal.

Secara keseluruhan prestasi belajar peserta didik menunjukkan rata-rata 82,5 dengan standar KKM 80. Kendati demikian prestasi 


\section{Hartinawanti. Pengaruh Iklim Sekolah dan Kreativitas Pembelajaran Terhadap Prestasi Belajar IPS Peserta Didik di SD Kartika XX-I Kecamatan Mamajang Kota Makassar}

belajar tersebut masih tergolong belum maksimal dikarenakan sekolah tersebut merupakan sekolah unggulan dengan target prestasi belajar maksimal adalah 100. Setelah dilakukan observasi lebih mendalam diketahui bahwa hal ini dikarenakan peserta didik belum mampu mengembangkan kreativitas dalam dirinya hal ini terlihat dalam proses pembelajaran peserta didik hanya mengikuti arahan guru disetiap pembelajaran IPS. Masih banyak peserta didik yang belum memanfaatkan teknologi pembelajaran.

Berdasarkan masalah yang telah dikemukakan di atas maka penulis tertarik untuk melakukan penelitian di SD Kartika XX-I Kecamatan Mamajang Kota Makassar dengan judul penelitian "Pengaruh iklim sekolah dan kreativitas pembelajaran terhadap prestasi belajar IPS peserta didik di SD Kartika XX-I Kecamatan Mamajang Kota Makassar"

Berdasarkan latar belakang diatas maka yang menjadi rumusan masalah dalam penelitian ini adalah: (1) Apakah ada pengaruh antara iklim sekolah terhadap prestasi belajar IPS di SD Kartika XX-I Kecamatan Mamajang Kota Makassar?; (2) Apakah ada pengaruh antara kreativitas pembelajaran terhadap prestasi belajar IPS di SD Kartika XX-I Kecamatan Mamajang Kota Makassar?; (3) Apakah ada pengaruh secara bersama-sama antara iklim sekolah dan kreativitas pembelajaran terhadap prestasi belajar IPS di SD Kartika XX-I Kecamatan Mamajang Kota Makassar?

Pada prinsipnya tujuan yang ingin dicapai di dalam penelitian ini adalah untuk mengetahui: (1) pengaruh antara iklim sekolah terhadap prestasi belajar IPS di SD Kartika XX-I Kecamatan Mamajang Kota Makassar; (2) pengaruh antara kreativitas pembelajaran terhadap prestasi belajar IPS di SD Kartika XX-I Kecamatan Mamajang Kota Makassar; (3) pengaruh secara bersama-sama antara iklim sekolah dan kreativitas pembelajaran terhadap prestasi belajar IPS di SD Kartika XX-I Kecamatan Mamajang Kota Makassar.

Menurut (Stichter 2008:45), iklim sekolah didefinisikan sebagai persepsi bersama tentang apa yang sedang terjadi secara akademis, secara social, dan lingkungan di sekolah secara rutin. Indikator iklim sekolah (Mulyasa 2016) dalam penelitian ini adalah: Kenyamanan, pembelajaran, hubungan antara civitas sekolah, serta suasana dan kebersihan sekolah.
Kreativitas adalah modifikasi sesuatu yang sudah ada menjadi konsep baru. Dengan kata lain, terdapat dua konsep lama yang dikombinasikan menjadi suatu konsep baru (Semiawan 2009:44). Pembelajaran adalah suatu proses dimana lingkungan seseorang secara disengaja dikelola untuk memungkinkan ia turut serta dalam tingkah laku dalam kondisi khusus atau menghasilkan respon terhadap situasi tertentu (Corey 2011:195).

\section{METODE PENELITIAN}

Penelitian ini adalah jenis penelitian ex post facto. Populasi meliputi seluruh peserta didik SD Kartika XX-I Kecamatan Mamajang yang berjumlah 265 peserta didik tahun ajaran 2017/2018. Jumlah sampel yaitu 159 peserta didik pada 6 kelas (rombel) sampel yakni peserta didik kelas III A, peserta didik kelas III B, peserta didik kelas IV A, peserta didik kelas IV B, peserta didik kelas V A, dan peserta didik kelas V B. Teknik penarikan sampel yang digunakan dalam penelitian ini adalah multistage random sampling.

Teknik pengumpulan data dan instrument penelitian yang digunakan dalam penelitian ini yaitu angket, observasi dan dokumentasi. Instrumen pengukuran yang digunakan dalam penelitian ini telah divalidasi meliputi Validasi rasional dan Validasi Empiris. Teknik Analisa Data meliputi analisis statistik desktiptif dan analisis inferensial. Analisis ini diawali dengan uji syarat analisis yaitu uji normalitas, uji linieritas, dan wilayah uji hipotesis (uji regresi).

\section{HASIL DAN PEMBAHASAN}

1. Pengaruh yang signifikan antara iklim sekolah terhadap prestasi belajar IPS peserta didik SD Kartika XX-I Kecamatan Mamajang Kota Makassar

a. Deskripsi iklim sekolah

Data hasil analisis deskriptif variabel iklim sekolah pada peserta didik SD Kartika XX-I Kecamatan Mamajang Kota Makassar yang diperoleh dari angket penelitian, secara umum berdasarkan hasil angket (tabel 4.1), maka dapat dijelaskan bahwa skor tersebar pada rentang 58 (skor terendah) sampai 100 (skor tertinggi). Ringkasan hasil analisis deskriptif variabel iklim sekolah pada peserta didik SD Kartika XX-I 


\section{Hartinawanti. Pengaruh Iklim Sekolah dan Kreativitas Pembelajaran Terhadap Prestasi Belajar IPS Peserta Didik di SD Kartika XX-I Kecamatan Mamajang Kota Makassar}

Kecamatan Mamajang Kota Makassar, disajikan pada tabel 4.1 berikut:

\begin{tabular}{ll} 
Tabel 4.1. & Statistik Skor iklim sekolah \\
\hline Uraian & Besaran Statistik \\
\hline Jumlah skor & 12469 \\
Rata-rata (Mean) & 78,42 \\
Nilai Tengah (Median) & 78 \\
Standar Deviasi & 11,776 \\
Range & 42 \\
Skor minimum & 58 \\
Skor maksimum & 100 \\
\hline
\end{tabular}

Sumber: Hasil Analisis Angket, 2018

Hasil perhitungan statistik deskriptif yang didasarkan frekuensi pilihan responden terhadap kategori jawaban, diperoleh skor rata-rata (mean) sebesar 78,42 dengan jumlah skor 12469 dari 159 responden penelitian di SD Kartika XX-I Kecamatan Mamajang Kota Makassar. Gambaran distribusi frekuensi dan persentase iklim sekolah pada peserta didik SD Kartika XX-I Kecamatan Mamajang Kota Makassar, disajikan pada tabel 4.2 berikut:

Tabel 4.2. Distribusi Frekuensi dan Persentase Skor iklim sekolah

\begin{tabular}{llll}
\hline Interval & iklim sekolah & F & $\%$ \\
\hline $84-100$ & Sangat kondusif & 55 & 34,59 \\
$68-83$ & Kondusif & 69 & 43,39 \\
$52-67$ & Cukup kondusif & 35 & 22,01 \\
$36-51$ & Kurang kondusif & 0 & 0 \\
$20-35$ & Sangat kurang kondusif & 0 & 0 \\
\hline & J u m l a h & 159 & 100,00
\end{tabular}

Sumber: Hasil Analisis Angket, 2018

Berdasarkan tabel 4.2 tentang iklim sekolah pada peserta didik SD Kartika XX-I Kecamatan Mamajang Kota Makassar tersebut, dapat dilihat bahwa sebagian besar responden menyatakan iklim sekolah pada peserta didik di SD Kartika XX-I Kecamatan Mamajang Kota Makassar berada dalam kategori sangat tinggi sebanyak 55 responden (34.59 persen), kategori tinggi sebanyak 69 responden (43.39 persen), kategori cukup sebanyak 35 responden (22.01 persen). Sesuai nilai rata-rata skor hasil penelitian tentang iklim sekolah pada peserta didik SD Kartika XX-I Kecamatan Mamajang Kota Makassar sebesar 78,42. Berdasarkan tabel prestasi belajar IPS peserta didik di atas, dapat diketahui bahwa pada umumnya iklim sekolah IPS pada peserta didik SD Kartika XX-I Kecamatan Mamajang Kota Makassar berada pada kategori tinggi dengan persentase $43.39 \%$ dengan frekuensi 69 orang responden dari 159 orang responden.

\section{b. Hasil uji Hipotesis I}

Dalam pengujian statistiknya, hipotesis dirumuskan sebagai berikut:

$\mathbf{H}_{\mathbf{0}}: \boldsymbol{\beta}_{\mathbf{1}}=\mathbf{0}$ Vs $\mathbf{H}_{\mathbf{1}}: \boldsymbol{\beta}_{\mathbf{1}} \neq \mathbf{0}$

$\mathrm{H}_{0}$ : Tidak terdapat pengaruh yang signifikan antara iklim sekolah terhadap prestasi belajar IPS peserta didik SD Kartika XX-I Kecamatan Mamajang Kota Makassar.

$\mathrm{H}_{1} \quad$ : Terdapat pengaruh yang signifikan antara iklim sekolah dengan prestasi belajar IPS peserta didik SD Kartika XX-I Kecamatan Mamajang Kota Makassar.

Dari hasil analisis dengan SPSS diperoleh nilai signifikansi $=0.000$. Terlihat bahwa $\alpha>$ signifikansi dengan demikian $\mathrm{H}_{0}$ ditolak sehingga $\mathrm{H}_{1}$ yang menyatakan bahwa terdapat pengaruh yang signifikan antara tingkat iklim sekolah terhadap prestasi belajar IPS peserta didik SD Kartika XX-I Kecamatan Mamajang Kota Makassar dapat diterima.

Persamaan regresi linier Y (prestasi belajar IPS) atas X1 (iklim sekolah) yang diperoleh dari perhitungan yang telah dilakukan adalah $\mathrm{Y}=99,937-0.146 \mathrm{X} 1$. Persamaan regresi $\mathrm{Y}$ atas X1 tersebut menunjukkan bahwa setiap kenaikan satu unit X1 akan mengakibatkan 0.146 unit penurunan Y. Hal ini menunjukkan bahwa terdapat hubungan antara $\mathrm{X} 1$ dengan $\mathrm{Y}$. Besarnya koefisien determinasi (R2) adalah 0.172 , ini berarti pengaruh atau kontribusi $\mathrm{X} 1$ terhadap Y adalah sebesar $1.72 \%$. Dengan kata lain variasi dalam variabel $\mathrm{Y}$ sekitar $1.72 \%$ dapat dijelaskan oleh variabel $\mathrm{X} 1$ melalui persamaan regresi $\mathrm{Y}=99,937-0.146 \mathrm{X} 1$, Dengan demikian hipotesis pertama yang menyatakan terdapat pengaruh yang signifikan antara iklim sekolah dengan prestasi belajar IPS peserta didik SD Kartika XX-I Kecamatan Mamajang Kota Makassar dapat diterima.

2. Pengaruh yang signifikan antara kreativitas pembelajaran terhadap prestasi belajar IPS peserta didik SD Kartika XX-I Kecamatan Mamajang Kota Makassar

a. Deskripsi kreativitas pembelajaran

Data hasil analisis deskriptif variabel kreativitas pembelajaran peserta didik SD Kartika XX-I Kecamatan Mamajang Kota Makassar yang diperoleh dari angket penelitian, secara umum 


\section{Hartinawanti. Pengaruh Iklim Sekolah dan Kreativitas Pembelajaran Terhadap Prestasi Belajar IPS Peserta Didik di SD Kartika XX-I Kecamatan Mamajang Kota Makassar}

berdasarkan hasil angket (tabel 4.3), maka dapat dijelaskan bahwa skor tersebar pada rentang 57 (skor terendah) sampai 98 (skor tertinggi). Ringkasan hasil analisis deskriptif variabel kreativitas pembelajaran peserta didik SD Kartika XX-I Kecamatan Mamajang Kota Makassar, disajikan pada tabel 4.3 berikut:

\begin{tabular}{|c|c|}
\hline $\begin{array}{l}\text { Tabel } 4.3 \text {. } \\
\text { pembelajaran }\end{array}$ & kreativita \\
\hline Uraian & Besaran Statistik \\
\hline Jumlah skor & 12322 \\
\hline Rata-rata (Mean) & 77,50 \\
\hline Nilai Tengah (Median) & 77 \\
\hline Standar Deviasi & 11,881 \\
\hline Range & 41 \\
\hline Skor minimum & 57 \\
\hline Skor maksimum & 98 \\
\hline
\end{tabular}

Sumber: Hasil Analisis Angket, 2018

Hasil perhitungan statistik deskriptif yang didasarkan frekuensi pilihan responden terhadap kategori jawaban, diperoleh skor rata-rata (mean) sebesar 77,50 dengan jumlah skor 12322 dari 159 responden penelitian di SD Kartika XX-I Kecamatan Mamajang Kota Makassar. Gambaran distribusi frekuensi dan persentase kreativitas pembelajaran peserta didik SD Kartika XX-I Kecamatan Mamajang Kota Makassar, disajikan pada tabel 4.4 berikut:

Tabel 4.4. Distribusi Frekuensi dan Persentase Skor kreativitas pembelajaran

\begin{tabular}{llll}
\hline Interval & $\begin{array}{l}\text { Kreativitas } \\
\text { pembelajaran }\end{array}$ & F & $\%$ \\
\hline $84-100$ & Sangat kreatif & 47 & 29,55 \\
$68-83$ & Kreatif & 71 & 44,65 \\
$52-67$ & $\begin{array}{l}\text { Cukup kreatif } \\
\text { Kurang kreatif }\end{array}$ & 41 & 25,78 \\
$36-51$ & $\begin{array}{l}\text { Sangat kurang } \\
20-35\end{array}$ & 0 & 0 \\
& $\begin{array}{l}\text { kreatif } \\
\text { J u m la h }\end{array}$ & 159 & 100,00
\end{tabular}

Sumber: Hasil Analisis Angket, 2018

Berdasarkan tabel 4.4 tentang kreativitas pembelajaran peserta didik SD Kartika XX-I Kecamatan Mamajang Kota Makassar tersebut, dapat dilihat bahwa sebagian besar responden menyatakan kreativitas pembelajaran peserta didik SD Kartika XX-I Kecamatan Mamajang Kota Makassar dalam kategori sangat tinggi sebanyak 47 responden (29,55 persen), kategori tinggi sebanyak 71 responden (44,65 persen), kategori cukup sebanyak 41 responden $(25,78$ persen). Sesuai nilai rata-rata skor hasil penelitian tentang kreativitas pembelajaran peserta didik SD Kartika XX-I Kecamatan Mamajang Kota Makassar sebesar 77,50. Berdasarkan tabel kreativitas pembelajaran peserta didik di atas, dapat diketahui bahwa pada umumnya kreativitas pembelajaran peserta didik SD Kartika XX-I Kecamatan Mamajang Kota Makassar berada pada kategori tinggi dengan persentase $44,65 \%$ dengan frekuensi 71 orang responden dari 159 orang responden.

\section{b. Hasil uji Hipotesis II}

Dalam pengujian statistiknya, hipotesis dirumuskan sebagai berikut:

$\mathbf{H}_{\mathbf{0}}: \boldsymbol{\beta}_{\mathbf{1}}=\mathbf{0}$ Vs $\mathbf{H}_{\mathbf{1}}: \boldsymbol{\beta}_{\mathbf{1}} \neq \mathbf{0}$

$\mathrm{H}_{0}$ : Tidak terdapat pengaruh yang signifikan antara kreativitas pembelajaran terhadap prestasi belajar IPS peserta didik SD Kartika XX-I Kecamatan Mamajang Kota Makassar.

$\mathrm{H}_{1} \quad$ : Terdapat pengaruh yang signifikan antara kreativitas pembelajaran terhadap prestasi belajar IPS peserta didik SD Kartika XX-I Kecamatan Mamajang Kota Makassar.

Dari hasil analisis dengan SPSS diperoleh nilai signifikansi $=0.000$. Terlihat bahwa $\alpha>$ signifikansi dengan demikian $\mathrm{H}_{0}$ ditolak sehingga $\mathrm{H}_{1}$ yang menyatakan bahwa terdapat pengaruh yang signifikan kreativitas pembelajaran terhadap prestasi belajar IPS peserta didik SD Kartika XX-I Kecamatan Mamajang Kota Makassar dapat diterima.

Persamaan regresi linier Y (prestasi belajar IPS) atas X2 (kreativitas pembelajaran) yang diperoleh dari perhitungan yang telah dilakukan adalah $Y=75,982+0.161 X_{2}$. Persamaan regresi $\mathrm{Y}$ atas $\mathrm{X} 2$ tersebut menunjukkan bahwa setiap kenaikan satu unit X2 akan mengakibatkan 0.161 unit kenaikan Y. Hal ini menunjukkan bahwa terdapat hubungan antara $\mathrm{X} 2$ dengan $\mathrm{Y}$

Besarnya koefisien determinasi (R2) adalah 0.216 , ini berarti pengaruh atau kontribusi $\mathrm{X} 2$ terhadap Y adalah sebesar 2,16\%. Dengan kata lain variasi dalam variabel $\mathrm{Y}$ sekitar $2,16 \%$ dapat dijelaskan oleh variabel X2 melalui persamaan regresi $\mathrm{Y}=75,982-0.161 \mathrm{X} 1$, Dengan demikian hipotesis kedua yang menyatakan terdapat kreativitas pembelajaran terhadap prestasi belajar IPS peserta didik SD 


\section{Hartinawanti. Pengaruh Iklim Sekolah dan Kreativitas Pembelajaran Terhadap Prestasi Belajar IPS Peserta Didik di SD Kartika XX-I Kecamatan Mamajang Kota Makassar}

Kartika XX-I Kecamatan Mamajang Kota Makassar dapat diterima.

3. Pengaruh iklim sekolah dan kreativitas pembelajaran terhadap prestasi belajar IPS peserta didik SD Kartika XX-I Kecamatan Mamajang Kota Makassar

a. Deskripsi prestasi belajar

Data hasil analisis deskriptif variabel prestasi belajar IPS pada peserta didik SD Kartika XX-I Kecamatan Mamajang Kota Makassar yang diperoleh dari tes prestasi belajar, secara umum berdasarkan hasil angket (tabel 4.5), maka dapat dijelaskan bahwa skor tersebar pada rentang 80 (skor terendah) sampai 100 (skor tertinggi). Gambaran distribusi frekuensi dan persentase prestasi belajar IPS pada peserta didik SD Kartika XX-I Kecamatan Mamajang Kota Makassar, disajikan pada tabel 4.5 berikut:

Tabel 4.5. Distribusi Frekuensi dan Persentase Skor Prestasi Belajar IPS

\begin{tabular}{llll}
\hline Interval & $\begin{array}{l}\text { Prestasi belajar } \\
\text { IPS }\end{array}$ & $\mathrm{F}$ & $\%$ \\
\hline $84-100$ & Sangat tinggi & 117 & 73,58 \\
$67-83$ & Tinggi & 42 & 26,42 \\
$50-66$ & Cukup & 0 & 0 \\
$33-49$ & Kurang & 0 & 0 \\
$0-32$ & Sangat kurang & 0 & 0 \\
\hline & J u m l a h & 159 & 100
\end{tabular}

Sumber: Hasil Analisis Angket, 2018

Berdasarkan tabel 4.5 tentang prestasi belajar IPS pada peserta didik SD Kartika XX-I Kecamatan Mamajang Kota Makassar tersebut, dapat dilihat bahwa sebagian besar responden menyatakan prestasi belajar IPS pada peserta didik SD Kartika XX-I Kecamatan Mamajang Kota Makassar berada dalam kategori sangat tinggi sebanyak 117 responden (73,58 persen), kategori tinggi sebanyak 42 responden $(26,42$ persen). Sesuai nilai rata-rata skor hasil penelitian tentang prestasi belajar IPS pada peserta didik di SD Kartika XX-I Kecamatan Mamajang Kota Makassar sebesar 88,50. Berdasarkan tabel prestasi belajar IPS peserta didik di atas, dapat diketahui bahwa pada umumnya prestasi belajar IPS pada peserta didik SD Kartika XX-I Kecamatan Mamajang Kota Makassar berada pada kategori sangat tinggi dengan persentase $73,58 \%$ dengan frekuensi 117 orang responden dari 159 orang responden. Ringkasan hasil analisis deskriptif variabel prestasi belajar IPS pada peserta didik SD Kartika XX-I Kecamatan Mamajang Kota Makassar, disajikan pada tabel 4.6 berikut:

Tabel 4.6. Statistik Skor Prestasi Belajar IPS

\begin{tabular}{ll}
\hline Uraian & Besaran Statistik \\
\hline Jumlah skor & 14071 \\
Rata-rata (Mean) & 88,50 \\
Nilai Tengah (Median) & 88 \\
Standar Deviasi & 4,081 \\
Range & 17 \\
Skor minimum & 80 \\
Skor maksimum & 97
\end{tabular}

Sumber: Hasil Analisis Tes Prestasi Belajar IPS, 2018

Hasil perhitungan statistik deskriptif yang didasarkan frekuensi pilihan responden terhadap kategori jawaban, diperoleh skor rata-rata (mean) sebesar 88,50 dengan jumlah skor 14071 dari 159 responden penelitian SD Kartika XX-I Kecamatan Mamajang Kota Makassar.

b. Hasil uji Hipotesis III

Dalam pengujian statistiknya, hipotesis dirumuskan sebagai berikut:

$\mathbf{H}_{\mathbf{0}}: \boldsymbol{\beta}_{\mathbf{i}}=\mathbf{0}$ Vs $\mathbf{H}_{\mathbf{1}}: \boldsymbol{\beta}_{\mathbf{i}} \neq \mathbf{0},(\exists \mathrm{i} \neq 0)$

$\mathrm{H}_{0}$ : Tidak terdapat pengaruh yang signifikan secara bersama-sama antara iklim sekolah dan kreativitas pembelajaran terhadap prestasi belajar IPS peserta didik SD Kartika XX-I Kecamatan Mamajang Kota Makassar.

$\mathrm{H}_{1} \quad$ : $\quad$ Terdapat pengaruh yang signifikan secara bersama-sama antara iklim sekolah dan kreativitas pembelajaran terhadap prestasi belajar IPS peserta didik SD Kartika XX-I Kecamatan Mamajang Kota Makassar.

Dari hasil analisis dengan SPSS diperoleh nilai signifikansi $=0.000$. Terlihat bahwa $\alpha>$ signifikansi dengan demikian $\mathrm{H}_{0}$ ditolak sehingga $\mathrm{H}_{1}$ yang menyatakan bahwa terdapat pengaruh yang signifikan secara bersama-sama antara iklim sekolah dan kreativitas pembelajaran terhadap prestasi belajar IPS peserta didik SD Kartika XX-I Kecamatan Mamajang Kota Makassar dapat diterima. Persamaan regresi linier Y (prestasi belajar IPS) atas $\mathrm{X}_{1}$ dan $\mathrm{X}_{2}$, (iklim sekolah dan kreativitas pembelajaran) yang diperoleh dari perhitungan yang telah dilakukan adalah $\mathrm{Y}=87.076-$ $0.119 \mathrm{X}_{1}+0.139 \mathrm{X}_{2}$. Persamaan regresi $\mathrm{Y}$ atas $\mathrm{X}_{1}$ dan $\mathrm{X}_{2}$ tersebut menunjukkan bahwa 


\section{Hartinawanti. Pengaruh Iklim Sekolah dan Kreativitas Pembelajaran Terhadap Prestasi Belajar IPS Peserta Didik di SD Kartika XX-I Kecamatan Mamajang Kota Makassar}

setiap kenaikan satu unit $\mathrm{X}_{1}$ akan mengakibatkan 0.119 unit penurunan $\mathrm{Y}$, kenaikan satu unit $\mathrm{X}_{2}$ akan mengakibatkan 0.139 unit kenaikan Y. Hal ini menunjukkan bahwa terdapat hubungan antara $\mathrm{X}_{1}$ dan $\mathrm{X}_{2}$ dengan $\mathrm{Y}$. Besarnya koefisien determinasi (R2) adalah 0.327, ini berarti pengaruh atau kontribusi $\mathrm{X}_{1}$ dan $\mathrm{X}_{2}$ terhadap $\mathrm{Y}$ adalah sebesar $32.7 \%$. Dengan kata lain variasi dalam variabel $\mathrm{Y}$ sekitar $32.7 \%$ dapat dijelaskan oleh variabel $\mathrm{X}_{1}$ dan $\mathrm{X}_{2}$ melalui persamaan regresi $\mathrm{Y}=$ 87.076 - 0.119 $\mathrm{X}_{1}+0.139 \mathrm{X}_{2}$. Dengan demikian hipotesis pertama yang menyatakan terdapat pengaruh yang signifikan secara bersama-sama antara iklim sekolah dan kreativitas pembelajaran terhadap prestasi belajar IPS peserta didik SD Kartika XX-I Kecamatan Mamajang Kota Makassar dapat diterima.

\section{Pembahasan}

1. Pengaruh yang signifikan antara iklim sekolah terhadap prestasi belajar IPS peserta didik SD Kartika XX-I Kecamatan Mamajang Kota Makassar

Setiap sekolah memiliki berbagai macam kondisi yang dapat saling mempengaruhi satu sama lain. Salah satu kondisi yang memberikan kontribusi terhadap prestasi belajar adalah Iklim sekolah. Iklim sekolah merupakan suasana dalam suatu sekolah yang diciptakan oleh pola hubungan antar pribadi yang berlaku. Pola hubungan ini bersumber dari hubungan antar guru dengan guru lainnya atau mungkin hubungan antara guru dengan pemimpin atau sebaliknya antara pemimpin dengan guru serta antara guru dengan peserta didiknya. Subsistem yang paling penting dalam suatu sekolah adalah subsistem insani. Hal ini disebabkan berhasil atau tidaknya sekolah itu mencapai tujuan dan mempertahankan eksistensinya lebih banyak ditentukan oleh faktor manusianya. Oleh sebab itu, dalam melaksanakan aktivitasnya, manusia yang bekerja pada sekolah tersebut perlu disubstitusi dengan berbagai stimulus dan fasilitas yang dapat meningkatkan kebutuhan dan gairah aktivitas yang berhubungan dengan tugasnya masing-masing.

Hasil analisis data menunjukkan adanya pengaruh iklim sekolah terhadap prestasi belajar. Ini berarti bahwa semakin nyaman iklim sekolah semakin tinggi prestasi belajar dan sebaliknya semakin tidak nyaman iklim sekolah maka semakin rendah prestasi belajar.

Iklim sekolah yang nyaman serta kondusif yang didalamnya terdapat guru yang memiliki interest, peduli, adil, demokratis, dan respek terhadap peserta didiknya ternyata telah mampu mengurangi tingkat drop out peserta didik, tinggal kelas, dan perilaku salah di kalangan peserta didik. Selain berdampak positif pada pencapaian hasil akademik peserta didik, iklim sekolah pun memiliki kontribusi positif terhadap pencapaian hasil non akademik, seperti pembentukan konsep diri, keyakinan diri, dan aspirasi. Hal ini sesuai dengan pendapat Moedjiarto (2002) mengemukakan bahwa, iklim sekolah yang positif menunjukkan adanya rasa kekeluargaan yang kuat antara civitas sekolah yaitu pimpinan sekolah, guru, karyawan, peserta didik, dan orang tua. Iklim sekolah merupakan bagian dari lingkungan belajar yang akan mempengaruhi kepribadian dan tingkah laku seseorang, sebab dalam melaksanakan tugas sekolahnya seorang peserta didik akan selalu berinteraksi dengan lingkungan belajarnya.

Adapun cara yang bisa dilakukan untuk menciptakan hubungan yang serasi antara guru dan peserta didik menurut (Nursisto 2002:22), antara lain: (a) Tegur sapa dan salam, hal ini dilakukan beberapa menit sebelum jam pelajaran dimulai. Para bapak dan ibu guru datang lebih awal dari jam semestinya bertugas. Adapun tujuannya untuk menyambut peserta didik merasa diperhatikan, pihak sekolah dapat sekaligus melakukan ceking dengan adanya tersebut hubungan guru dengan peserta didik lebih dekat. (b) Ucapan selamat bagi peserta didik yang sukses, Ucapan ini merupakan upaya menjalin keakraban hubungan guru dengan peserta didik. Memberi penghargaan atau penghormatan bagi peserta didik yang berprestasi. Dengan arti prestasi yang sangat luas meliputi olah raga, kesenian, keterampilan, dan apapun yang bernilai plus. (c) Ucapan selamat bagi peserta didik yang berulang tahun, Keuntungannya adalah: Pertama, sekolah berkesan memperhatikan peserta didik. Kedua, sekolah bisa menyampaikan pesan-pesan lewat guru/wali kelas. Ketiga, menciptakan mental peserta didik karena pada hari ulang tahun itu diri peserta didik akan menjadi pusat perhatian, dirinya akan malu bila mempunyai citra yang buruk. Sehingga, peserta didik akan tersugesti 


\section{Hartinawanti. Pengaruh Iklim Sekolah dan Kreativitas Pembelajaran Terhadap Prestasi Belajar IPS Peserta Didik di SD Kartika XX-I Kecamatan Mamajang Kota Makassar}

berbuat baik dan terpuji. (d) Mengoleksi Foto, koleksi foto ini bisa ditempelkan dalam papan tempel, keuntungan yang dapat diambil adalah: Pertama, untuk kepentingan sekolah yaitu sekolah dapat mengenal individu peserta didik. Kedua, sekolah bisa mengenal wajah peserta didik dalam kaitannya dengan hal khusus. Ketiga, kepentingan orang luar ketika mencari peserta didik. (e) Penobatan guru favorit dan simpatik, penobatan ini dalam arti penuh kekeluargaan, terutama bila dikacamatakan dari tujuan sekolah yang terus menerus melakukan pembinaan. Penobatan guru simpatik, guru kasih sayang dan guru favorit adalah cara yang dapat dijadikan sarana untuk mengakrabkan hubungan guru dengan peserta didik.

Berdasarakan uraian diatas peneliti menyimpulkan ada pengaruh yang signifikan antara iklim sekolah terhadap prestasi belajar peserta didik di SD Kartika XX-I Kecamatan Mamajang Kota Makassar.

1. Pengaruh yang signifikan antara kreativitas pembelajaran terhadap prestasi belajar IPS peserta didik SD Kartika XX-I Kecamatan Mamajang Kota Makassar

Hasil analisis deskriptif menggambarkan adanya pengaruh kreativitas pembelajaran terhadap prestasi belajar peserta didik di SD Kartika XX-I Kecamatan Mamajang Kota Makassar. Rata-rata anak yang berprestasi sangat tinggi memiliki kreativitas tinggi. Ini berarti semakin kreatif peserta didik maka semakin tinggi pula prestasi belajarnya, begitupun sebaliknya semakin kurang kreativitas peserta didik semakin rendah pula prestasi belajarnya.

Pengembangan kreativitas siswa dalam proses pembelajaran merupakan hal penting, sebab jika kreativitas siswa tidak muncul maka proses pembelajaran tersebut akan statis, artinya tidak ada interaksi yang baik antara pendidik dan anak, oleh karena itu kita harus mengetahui dan memahami faktor-faktor yang mempengaruhi kreativitas belajar siswa. Kreativitas belajar dan konteks ini, berarti para siswa diharapkan mampu membuat koneksi (keterkaitan) atas diri mereka sendiri, untuk hadir dan menghasilkan kombinasi-kombinasi baru, untuk mengaplikasikan imajinasi dalam bahasa yang mereka gunakan. Hal ini sejalan dengan pendapat Munandar (2009:12), bahwa kreativitas adalah hasil interaksi antara individu dan lingkungannya, kemampuan untuk membuat kombinasi baru, berdasarkan data, informasi, atau unsur-unsur yang sudah ada atau dikenal sebelumnya, yaitu semua pengalaman dan pengetahuan yang telah diperoleh seseorang selama hidupnya baik itu di lingkungan sekolah, keluarga, maupun dari lingkungan masyarakat.

Sejalan dengan pendapat (Santrock 2013:366), kreativitas ialah kemampuan berpikir tentang sesuatu dengan cara baru dan tak biasa dan menghasilkan solusi yang unik atas suatu problem. Sementara Rogers (Munandar 2014:18), mengemukakan kreativitas adalah kecenderungan untuk mengaktualisasi diri, mewujudkan potensi, dorongan untuk berkembang dan menjadi matang, kecenderungan untuk mengekspresikan dan mengaktifkan semua kemampuan organisme. Definisi lain menurut Moreno (Riyanto 2014:233), kreativitas merupakan sesuatu yang baru bagi diri sendiri dan tidak harus merupakan sesuatu yang baru bagi orang lain atau dunia pada umumnya, misalnya seorang peserta didik menciptakan untuk dirinya sendiri suatu hubungan baru dengan peserta didik/orang lain. Berdasarakan uraian diatas peneliti menyimpulkan ada pengaruh yang signifikan antara kreativitas pembelajaran terhadap prestasi belajar IPS pada peserta didik di SD Kartika XX-I Kecamatan Mamajang Kota Makassar.

\section{Pengaruh iklim sekolah dan kreativitas pembelajaran terhadap prestasi belajar IPS peserta didik SD Kartika XX-I Kecamatan Mamajang Kota Makassar}

Hasil analisis deskriptif menggambarkan adanya pengaruh iklim sekolah dan kreativitas pembelajaran baik secara sendiri-sendiri maupun secara bersamaan terhadap prestasi belajar peserta didik di SD Kartika XX-I Kecamatan Mamajang Kota Makassar.

Iklim sekolah yang nyaman (kondusif) mempengaruhi peningkatan prestasi belajar peserta didik. Dimana iklim sekolah merupakan suasana yang memberikan pengaruh yang cukup besar bagi peningkatan prestasi belajar anak di sekolah. Sebab Iklim sekolah yang kondusif sangat dibutuhkan bagi guru dan peserta didik untuk menumbuhkan dorongan dalam diri tersebut untuk melakukan proses pembelajaran lebih bersemangat. 


\section{Hartinawanti. Pengaruh Iklim Sekolah dan Kreativitas Pembelajaran Terhadap Prestasi Belajar IPS Peserta Didik di SD Kartika XX-I Kecamatan Mamajang Kota Makassar}

Sementara kreativitas pembelajaran juga salah satu faktor internal dalam individu yang berperan dalam pencapaian prestasi belajar peserta didik. Dengan kreativitas ini peserta didik akan mampu mengembangkan langkahlangkah pemecahan masalah yang dihadapinya, spesifiknya adalah penyelesaian soal ujian.

Berdasarkan penelitian Tutriyanti (2017) dan Tirtiana (2013) iklim sekolah dan kreativitas pembelajaran secara bersama-sama memberikan kontribusi yang positif terhadap prestasi belajar peserta didik. Hasil analisis menunjukkan semakin tinggi tingkat kenyamanan iklim sekolah dan semakin tinggi kreativitas pembelajaran maka semakin tinggi pula prestasi belajar peserta didik.

Menurut (Stichter 2008:45), iklim sekolah didefinisikan sebagai persepsi bersama tentang apa yang sedang terjadi secara akademis, secara sosial, dan lingkungan di sekolah secara rutin. Sementara Hoy, Smith dan Sweetland (Milner dan Harriet Khoza 2008:158), menjelaskan bahwa iklim sekolah dipahami sebagai manifestasi dari kepribadian sekolah yang dapat dievaluasi dalam di sebuah kontinum dari iklim sekolah terbuka ke iklim sekolah tertutup. Iklim sekolah terbuka didasarkan pada rasa hormat, kepercayaan dan kejujuran, serta memberikan peluang kepada guru, manajemen sekolah dan peserta didik untuk terlibat secara konstruktif dan kooperatif dengan satu sama lain.

Peran seorang guru dalam mengembangkan iklim sekolah yang kondusif menurut (Hamalik 2013:139) sebagai berikut: (a) kreativitas yang mendorong peserta didik untuk lebih berminat terhadap pelajaran, memikirkan kebenaran tentang sesuatu dan mendapatkan waktu yang cukup; (b) kebebasan mengajar yang mereka temukan kepada peserta didik serta sabar dalam melayani peserta didik; (c) mempunyai kemampuan memanfaatkan sumber yang tersedia; (d) antusias, bergairah dan mempunyai kemauan yang kuat untuk melaksanakan tugasnya dalam kondisi apapun; (e) empati, yaitu kesediaan untuk selalu memperhatikan dan merasakan apa yang dirasakan peserta didik.

Menurut Munandar (Ali dan Mohammad Asrori 2014:53), mengemukakan bahwa faktor-faktor yang mempengaruhi kreativitas adalah usia, tingkat pendidikan orang tua, fasilitas yang tersedia, dan penggunaan waktu luang. Sementara (Hurlock 2011:11), berpendapat bahwa ada beberapa kondisi yang dapat meningkatkan kreativitas yaitu waktu, kesempatan menyendiri, dorongan, sarana, rangsangan dari lingkungan, hubungan orang tua dan anak yang tidak posesif, cara mendidik anak, kesempatan untuk memperoleh pengetahuan.

Dari beberapa pendapat yang dikemukakan di atas dapat disimpulkan bahwa antara iklim sekolah dan kreativitas pembelajaran mempunyai keterkaitan atau hubungan yang dapat mempengaruhi peningkatan prestasi belajar peserta didik di sekolah.

Peningkatan kualitas pembelajaran menuntut kemandirian guru untuk menciptakan suasana belajar yang kondusif, agar para peserta didik dapat mengembangkan aktivitas dan kreativitas belajarnya secara optimal, sesuai dengan kemampuannya masing-masing. Dari berbagai pengalaman dan pengamatan terhadap perilaku peserta didik dalam pembelajaran, aktivitas dan kreativitas dapat dikembangkan dengan memberi kepercayaan, komunikasi yang bebas, pengarahan diri, dan pengawasan yang tidak terlalu ketat.

Sehingga dapat disimpulkan bahwa ada pengaruh yang signifikan antara iklim sekolah dan kreativitas pembelajaran secara bersamasama terhadap prestasi belajar IPS pada peserta didik di SD Kartika XX-I Kecamatan Mamajang Kota Makassar.

\section{SIMPULAN DAN SARAN}

\section{A. Kesimpulan}

Berdasarkan hasil penelitian yang telah dilakukan tentang pengaruh iklim sekolah dan Kreativitas pembelajaran terhadap Prestasi Belajar IPS pada SD Kartika XX-I Kecamatan Mamajang Kota Makassar, disimpulkan sebagai berikut:

Iklim sekolah berpengaruh signifikan terhadap prestasi belajar IPS peserta didik di SD Kartika XX-I Kecamatan Mamajang Kota Makassar. Hal ini menunjukkan bahwa jika iklim sekolah kondusif maka prestasi belajar peserta didik juga akan tinggi.

Kreativitas pembelajaran berpengaruh signifikan terhadap prestasi belajar IPS peserta didik di SD Kartika XX-I Kecamatan Mamajang Kota Makassar. Hal ini menunjukkan bahwa jika kreativitas pembelajaran tinggi maka prestasi belajar peserta didik juga tinggi. 
Iklim sekolah dan kreativitas pembelajaran bersama-sama berpengaruh signifikan terhadap prestasi belajar IPS peserta didik di SD Kartika XX-I Kecamatan Mamajang Kota Makassar. Hal ini menunjukkan bahwa interaksi antara iklim sekolah dan kreativitas pembelajaran akan menunjukkan prestasi belajar peserta didik yang tinggi.

\section{B. Saran}

Sehubungan dengan simpulan penelitian di atas, maka disarankan sebagai berikut: (1) Untuk mencapai prestasi belajar IPS yang baik bagi peserta didik di SD Kartika XX-I Kecamatan Mamajang Kota Makassar hendaknya guru menciptakan iklim sekolah yang kondusif melalui kenyamanan, dukungan terhadap pembelajaran, membangun hubungan yang baik antar civitas sekolah, serta menjaga suasana dan kebersihan sekolah; (2) Untuk mencapai prestasi belajar IPS yang baik hendaknya peserta didik di SD Kartika XX-I Kecamatan Mamajang Kota Makassar dapat memiliki kreativitas pembelajaran yang baik melalui upaya pribadi kreatif, dorongan baik dari dalam diri peserta didik maupun dari luar diri peserta didik, berproses secara kreatif dan menghasilkan produk-produk yang kreatif; (3) Untuk mencapai prestasi belajar IPS yang baik hendaknya iklim sekolah dan kreativitas pembelajaran peserta didik ditingkatkan karena kedua variabel tersebut berinteraksi secara bersama-sama berpengaruh dalam meningkatkan prestasi belajar IPS peserta didik di SD Kartika XX-I Kecamatan Mamajang Kota Makassar.

\section{DAFTAR RUJUKAN}

Ali, Mohammad, dan Mohammad Asrori. 2014. Psikologi Remaja dan Perkembangan Peserta Didik. Jakarta: Bumi Aksara.

Corey, Gerald. 2011. Teori dan Praktek Konseling dan Psikoterapi. Bandung: Refika Aditama.

Hamalik, Oemar. 2013. Kurikulum dan Pembelajaran. Jakarta: Bumi Aksara.
Hurlock, Elizabeth B. 2011. Psikologi Perkembangan. Jakarta: Erlangga.

Milner, Karen, dan Harriet Khoza. 2008. A Comparison of teacher Sress and School Climate Across Schools with Different Matric Success Rates. South African Journal of Education (Online), Vol. 28: 155-73. (http://ajol.info/index.php/saje/article /viewfile/25151/4350, Diakses 20 Februari 2018).

Moedjiarto, 2002. Sekolah Unggul. Surabaya: Duta Graha Pustaka.

Mulyasa, H.E. 2016. Menjadi Guru Profesional: Menciptakan Pembelajaran Kreatif dan Menyenangkan. Bandung: PT Remaja Rosda Karya.

Munandar, Utami. 2014. Pengembangan Kreativitas Anak Berbakat. Jakarta: Rineka Cipta.

Nursisto. 2002. Peningkatan Prestasi Sekolah Menengah. Jakarta: Insan Cendikia.

Riyanto, Yatim. 2014. Paradigma Baru Pembelajaran: Sebagai Referensi bagi pendidik dalam Implementasi Pembelajaran yang Efektif dan Berkualitas. Jakarta: Kencana.

Santrock, John W. 2013. Life-span Development, Perkembangan Masa Hidup. Jakarta: Erlangga.

Semiawan, Conny R. 2009. Kreativitas dan Keberbakatan. Jakarta: PT Indeks.

Stichter, Kenneth. 2008. Studebt School Climate Perceptions as a Measure of School Distric Goal Attainment. Journal of Education Research \& Policy Studies. Vol 8 (1). 44-46. 
Syah, Muhibbin. 2012. Psikologi Belajar.

Jakarta: RajaGrafindo Persada.

Tirtiana, Chandra Putri. 2013. Pengaruh Kreativitas Belajar, Penggunaan Media Pembelajaran Power Point, dan Lingkungan Keluarga Terhadap Hasil Belajar Mata Pelajaran Akuntansi Pada Peserta didik Kelas $\mathrm{X}$ Akt SMK Negeri 2 Blora Tahun Ajaran 2012/2013 (Motivasi Belajar Sebagai Variabel Intervening). Economic Education Analysis Journal (Online), Vol. 2 (2). (http://journal.unnes.ac.id/sju/index. php/eeaj, Diakses 04 Mei 2018).

Tutriyanti, Dwi Halima. 2017. "Pengaruh Iklim Sekolah dan Kecerdasan Emosional Terhadap Prestasi Belajar." Jurnal Penelitian dan Pendidikan IPS (Online), Vol. 9 (2). (http://ejournal.unikama.ac.id/index. php/JPPI, Diakses 04 Mei 2018). 